\title{
Antioxidant capacity and total polyphenol content of Lavandula cultivars at different growing areas in Hungary
}

\author{
Détár, E., Zámboriné Németh, É. \& Pluhár, Zs. \\ Department of Medicinal and Aromatic Plants, Faculty of Horticultural Science, \\ Szent István University, Villányi str. 29-43, 1118 Budapest, Hungary \\ Author for correspondence: eniko.detar@phd.uni-szie.hu
}

\begin{abstract}
Summary: Lavandula species are worldwide grown essential oil producing medicinal plants with considerable economic value. Beside volatile oil, lavender also contains different phenolic compounds which have been less widely studied till now. Cultivation of lavender has become widespread in Hungary in the recent years, however, growers have limited knowledge on the productivity of cultivars available. In our research we were aimed to studying the antioxidant capacity and total polyphenol content of samples collected in two growing areas (Dörgicse and Szomód) from flowers of two L. angustifolia ('Hidcote', 'Munstead') and two L. × intermedia ('Grosso', Grappenhall') varieties, during the full blooming period of 2017. Antioxidant capacity of the samples was determined by FRAP assay (Benzie and Strain, 1996), while total polyphenol content (TPC) was measured by a modified method of Singleton and Rossi (1965). According to our results, varieties of $L$. $\times$ intermedia showed higher values of antioxidant capacity and of total polyphenol content, than those of $L$. angustifolia cultivars. Among them, both the antioxidant capacity (179.6 mg AAE/g DW) and total polyphenol content values (152.4 mg GAE/g DW) of 'Grosso' from Dörgicse were the highest. Concerning FRAP values of all the cultivars investigated, larger variability were found in Dörgicse, than in Szomód. Regarding the effect of growing area, each cultivar represented similar FRAP values in Dörgicse and in Szomód, except for 'Grosso'. However, in the case of TPC values, higher variability was observed between the growing areas, especially in the case of 'Grosso'. In the future our studies on lavender polyphenols will be completed with qualitative evaluation of the values obtained by HPLC analysis.
\end{abstract}

Détár, E., Zámboriné Németh, É., Pluhár, Zs. (2020): Antioxidant capacity and total polyphenol content of Lavandula cultivars at different growing areas in Hungary. International Journal of Horticultural Science 26: 65-69. https://doi.org/ $10.31421 / \mathrm{IJHS} / 26 / 2020 / 5748$

Key words: lavender cultivars, antioxidant capacity, total polyphenol content, growing area

\section{Abbreviations}

AAE ascorbic acid equivalent

DW dry weight

FRAP ferric reducing antioxidant power

\section{Introduction}

Lavender is a valuable essential oil producing medicinal plant belonging to the Lamiaceae family. Several species are involved in the genus Lavandula, among them, L. angustifolia and $L . x$ intermedia are the most important. Both species are mainly grown for their essential oil, which is mainly used in the cosmetic industry and perfumery, in addition in aromatherapy (Lis-Balchin, 2002; Grant et al., 2011). However, it is important to draw the attention to other biologically active compounds accumulated in the plant, including polyphenols. Aqueous or methanolic extracts from lavender flowers or leaves also show beneficial pharmacological effects owing to phenoloid compounds. The most important property associated with polyphenols is the antioxidant activity. Natural antioxidants are applied in health care as well as in food preservation. The safety of the synthetic antioxidants have been questioned. Several preservatives have a destructive effect on human skin and they can be a possible carcinogenic agent (Darbre et al., 2004). The majority of preservatives of the cosmetics industry are artificially synthesized chemical compounds. However, currently the
GAE gallic acid equivalent

TPC total polyphenol content attention of many researchers has been focused on the usage of medicinal plants as sources of natural antioxidants.

According to Ceylan et al. (2015) methanolic extract of Lavandula stoechas might be a new potential natural antioxidant source, due to high antioxidant activity. Torras-Claveria et al. (2007) and Sánchez-Vioque et al. (2013) also proved antioxidant activity and total polyphenol content of lavandin waste after essential oil distillation with different extraction methods. In the study of Andrys et al. (2017), L. angustifolia 'Munstead' was

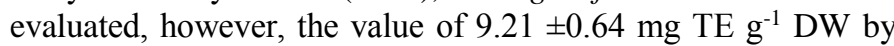
FRAP method, was significantly lower than the other two cultivars involved ('Ellagance Purple', 'Blue River'). Based on the study of Nurzyńska-Wierdak \& Zawiślak (2016), high positive correlation was found between the essential oil contents and antioxidant activity (AA) $(\mathrm{R}=0.9688)$, and total phenolic acids (AA) $(\mathrm{R}=0.9303)$ at $L$. angustifolia samples. It was also established by Shafaghat et al. (2012); and Zielinska \& Matkowski (2014) that the synthesis and accumulation of other polyphenols is changing during plant development and depend upon climatic factors. The antioxidant activity of plant extracts 
can be explained by the structure of phenolic compounds. Considering the above mentioned, the essential oil and phenolic content as well as their corresponding antioxidant potential of diverse plant organs were assayed by Nurzyńska-Wierdak \& Zawiślak (2016). According to their study antioxidant activity (AA) of leaves, flower buds and flowers were $77.5 \%, 85.9 \%$ and $86.3 \%$, respectively. In the research of Blažeković (2010), authors evaluated the effectiveness of inflorescence stalk extracts, as well as flower and leaf. It was shown that the leaf extracts of the two Lavandula taxa involved were the most active, followed by flower extracts, while the inflorescence stalk extracts showed lower antioxidant activity. In the study of Duda et al. (2015), higher amount of phenolics are detected at the beginning of flowering than in full bloom phase.

According to previous studies, a lack of scientific information can be seen on evaluating the effect of the environmental conditions to the polyphenol production of Lavandula varieties, while it is also an important issue. In our study, it was the first time that we have investigated the antioxidant capacity and total polyphenol values of different cultivars of L. angustifolia and L. $\times$ intermedia grown in distinct areas of Hungary. Our aim was to evaluate the effects of genotype as well as environmental factors on the FRAP and TPC values of Lavandula samples collected from 2 lavender and 2 lavandin cultivars in full flowering phase from 2 growing areas (Dörgicse, Szomód).

\section{Materials and methods}

\section{Plant material and sampling}

Two L. angustifolia (true lavender) cultivars, 'Munstead' $(\mathrm{Mu})$ and 'Hidcote' (Hi), as well as two L. $\times$ intermedia (lavandin) varieties, 'Grosso' (Gro), and 'Grappenhall' (Gra) were studied. Sampling was carried out on $14^{\text {th }}$ June (true lavender), and $14^{\text {th }}$ July (lavandin), at full blooming period, in 2017 in 3 replications at each variety. All the flower samples were dried and stored at room temperature until the laboratory analysis.

\section{Growing areas}

Growing areas are located in the Northern Transdanubia: in Dörgicse and Szomód where the lavender fields were established in 2003, and 2013, respectively. Dörgicse lies on 200 $\mathrm{m}$ high on Balaton Uplands, and has rocky brown forest soil with limestone base rock. There the climate is moderately warm, and the average annual rainfall is higher than $600 \mathrm{~mm}$. Szomód is a small village near Tata. It has sandy brown forest soil with loess base rock. The climate of Szomód is colder than the average climate at other areas of the country, and it has average annual rainfall between $650-700 \mathrm{~mm}$. General environmental conditions and soil characteristics of the distinct growing areas are included in Table $1 / \boldsymbol{a}$ and in Table $\mathbf{1 / b}$, while monthly precipitation values prior to harvest are also shown in Table 1/c.

\section{Preparation of extracts}

Dried flower samples were turned into powder by grinding. $0.5 \mathrm{~g}$ of the powder was extracted by $50 \mathrm{ml}$ boiling distilled water and was kept at room temperature for 24 hours. Then the extracts were filtered and stored in freezer prior the measurements.
Table 1/a. Environmental conditions of the growing areas involved.

\begin{tabular}{|l|c|c|}
\hline \multirow{2}{*}{ Study conditions } & \multicolumn{2}{|c|}{ Characteristics of the growth areas } \\
\cline { 2 - 3 } & Dörgicse & Szomód \\
\hline Region & $\begin{array}{c}\text { Balaton Uplands, } \\
\text { Veszprém County }\end{array}$ & $\begin{array}{c}\text { NE-Transdanubia, } \\
\text { Komárom Esztergom } \\
\text { County }\end{array}$ \\
\hline $\begin{array}{l}\text { Exposure of } \\
\text { growing area }\end{array}$ & plain & NW \\
\hline Location & $\begin{array}{c}46^{\circ} 55^{\prime} 01^{\prime \prime} \mathrm{N}, \\
17^{\circ} 43^{\prime} 19^{\prime \prime} \mathrm{E}\end{array}$ & $\begin{array}{c}47^{\circ} 40^{\prime} 57^{\prime \prime} \mathrm{N}, \\
18^{\circ} 20^{\prime} 30^{\prime \prime} \mathrm{E}\end{array}$ \\
\hline Base rock & limestone & 1 less \\
\hline Soil type & rocky brown forest soil & sandy brown forest soil \\
\hline $\begin{array}{l}\text { Average annual } \\
\text { temperature, }{ }^{\circ} \mathrm{C}\end{array}$ & $9-10$ & $8-9$ \\
\hline $\begin{array}{l}\text { Average annual } \\
\text { rainfall, mm }\end{array}$ & $600-650$ & $650-700$ \\
\hline $\begin{array}{l}\text { Lavender field } \\
\text { established in }\end{array}$ & 2003 & 2013 \\
\hline
\end{tabular}

\section{Ferric reducing/antioxidant power (FRAP) assay}

Ferric reducing/antioxidant power of Lavandula extracts was measured by the FRAP assay, according to the slight modification of the method of Benzie and Strain (1996). Reagents for the method were obtained from Sigma-Aldrich: Sodium-acetate, acetic acid, TPZ (2,4,6-tripiridil-s-triazine, hydrogen-chloride, iron-chloride. FRAP reagent was prepared prior to the measurements to contain sodium acetate buffer (pH=3.6), TPZ (2,4,6-tripiridil-s-triazine) in HCL and $\mathrm{FeCl}_{3} * 6 \mathrm{H}_{2} \mathrm{O}$ solution $(20 \mathrm{mmol} / \mathrm{l})$, in proportion of $10: 1: 1$ (v/v/v), respectively. 10-20-30 $\mu$ of test sample was added to $1.5 \mathrm{ml}$ of acting FRAP reagent and 40-30-20 $\mu$ l distilled water then the absorbance was recorded at $\lambda=593 \mathrm{~nm}$ after $5 \mathrm{~min}$ using the above spectrophotometer. A blank of distilled water was applied. FRAP values of samples were calculated from a standard curve equation and expressed in ascorbic acid equivalent based on the dry extract weight and expressed in $\mathrm{mg}$ AAE/g DW. The measurements were done in 3 replications in the case of every sample.

\section{Total polyphenol content assay}

Total phenol content of the extracts was determined by method of Singleton and Rossi (1965) with slight modifications. Reagents for the assay were purchased from Sigma-Aldrich: methanol, Folin-Ciocalteau reagent, sodium-carbonate, gallic acid. $25-50 \mu \mathrm{L}$ of sample solution was placed into a test tube then mixed with $2.5 \mathrm{~mL}$ Folin-Ciocalteau's reagent (10 v/v\%). After $1 \mathrm{~min}$ of incubation, $2 \mathrm{ml}$ of sodium carbonate $(0.7 \mathrm{M})$ was also added. The absorbance of the solution was measured at the wavelength of $\lambda=760 \mathrm{~nm}$ in a Thermo Evolution 201 spectrophotometer after a 5 min incubation period in hot water $\left(50{ }^{\circ} \mathrm{C}\right)$ in comparison with the blank of distilled water. Gallic acid $(0.3 \mathrm{M})$ was used as a chemical standard for calibration. The total phenolic content of the samples was expressed in gallic acid equivalent calculated on the dry weight basis of the extract (mg GAE/g DW). The measurements were done in 3 replications. 
Table 1/b. Soil characteristics of the growing areas of Lavandula in Dörgicse and Szomód (According to soil analyses of the growers).

\begin{tabular}{|c|c|c|c|c|c|c|c|c|c|c|c|c|c|}
\hline \multirow[b]{2}{*}{$\begin{array}{l}\text { Growing } \\
\text { locations }\end{array}$} & \multicolumn{13}{|c|}{ Soil parameters } \\
\hline & pH & $\mathbf{K}_{\mathbf{A}}$ & $\begin{array}{l}\mathrm{CaCO}_{3} \\
\mathrm{~m} / \mathrm{m} \%\end{array}$ & $\begin{array}{l}\text { Humus } \\
\mathrm{m} / \mathrm{m} \%\end{array}$ & $\begin{array}{c}\mathbf{N O}_{3}{ }^{-} \\
+\mathbf{N O}_{2}{ }^{-}-\mathbf{N} \\
\mathrm{mg} / \mathrm{kg} \\
\end{array}$ & $\begin{array}{c}\mathbf{P}_{2} \mathbf{O}_{\mathbf{5}} \\
\mathrm{mg} / \mathrm{kg}\end{array}$ & $\begin{array}{c}\mathbf{K}_{2} \mathbf{O} \\
\mathrm{mg} / \mathrm{kg}\end{array}$ & $\begin{array}{c}\mathbf{M g} \\
\mathrm{mg} / \mathrm{kg}\end{array}$ & $\begin{array}{c}\mathbf{N a} \\
\mathrm{mg} / \mathrm{kg}\end{array}$ & $\underset{\mathrm{mg} / \mathrm{kg}}{\mathbf{Z n}}$ & $\begin{array}{c}\mathbf{C u} \\
\mathrm{mg} / \mathrm{kg}\end{array}$ & $\underset{\mathrm{mg} / \mathrm{kg}}{\mathbf{M n}}$ & $\begin{array}{c}\mathbf{S O}_{4}{ }^{2-} \\
\mathrm{mg} / \mathrm{k} \\
\mathrm{g}\end{array}$ \\
\hline Dörgicse & 7 & 43 & 5 & 2 & 11 & 261 & 117 & 317 & 116 & 14 & 2 & 214 & 22 \\
\hline Szomód & 8 & 37 & 11 & 2 & 13 & 303 & 263 & 69 & 38 & 1 & 0 & 26 & 53 \\
\hline
\end{tabular}

Table 1/c. Quantity of precipitation (mm) prior to harvest period in 2017 (mm/month) (data were provided by OMSZ-National Meteorology Service).

\begin{tabular}{|l|c|c|}
\hline \multirow{2}{*}{ Growing area } & \multicolumn{2}{|c|}{ Amount of precipitation (mm/month) } \\
\cline { 2 - 3 } & Dörgicse & Szomód \\
\hline January & 20.3 & 23.0 \\
\hline February & 46.5 & 20.8 \\
\hline March & 20.9 & 41.3 \\
\hline April & 53.8 & 70.2 \\
\hline May & 15.2 & 23.6 \\
\hline June & 81.6 & 21.1 \\
\hline Total & 238.3 & 200.0 \\
\hline
\end{tabular}

Table 2. Evaluation of the effect of cultivars on the antioxidant capacity (FRAP) and total polyphenol content (TPC) in both growing areas (Dörgicse and Szomód) involved.

\begin{tabular}{|l|c|c|c|c|}
\hline \multirow{2}{*}{$\begin{array}{l}\text { Growing } \\
\text { area }\end{array}$} & Species & \multirow{2}{*}{ Cultivars } & \multicolumn{2}{|c|}{ Effect of cultivars } \\
\cline { 4 - 5 } & $\begin{array}{c}\text { L. } \\
\text { angustifolia }\end{array}$ & $\begin{array}{c}\text { 'Hidcote'- } \\
\text { 'Munstead' }\end{array}$ & $\mathrm{p}<0.0050^{* *}$ & $\mathrm{p}<0.0020^{* *}$ \\
\cline { 2 - 5 } & $\begin{array}{c}\text { L. } x \\
\text { intermedia }\end{array}$ & $\begin{array}{c}\text { 'Grosso'- } \\
\text { 'Grappenhall' }\end{array}$ & $\mathrm{p}<0.0001^{* *}$ & $\mathrm{p}<0.0020^{* *}$ \\
\cline { 2 - 5 } & & All cultivars & $\mathrm{p}<0.0001^{* *}$ & $\mathrm{p}<0.0001^{* *}$ \\
\hline \multirow{4}{*}{ Szomód } & $\begin{array}{c}\text { L. } x \\
\text { intermedia }\end{array}$ & $\begin{array}{c}\text { 'Hidcote'- } \\
\text { 'Gunstead' }\end{array}$ & $\mathrm{p}<0.1510$ & $\mathrm{p}<0.0260^{*}$ \\
\cline { 2 - 5 } & 'Grappenhall' & $\mathrm{p}<0.2510$ & $\mathrm{p}<0.0460^{*}$ \\
\cline { 2 - 5 } & & All cultivars & $\mathrm{p}<0.0001^{* *}$ & $\mathrm{p}<0.0001^{* *}$ \\
\hline
\end{tabular}

Legends: *: significant difference at $\mathrm{p}<0.05 ; * *$ : significant difference at $\mathrm{p}<0.01$

\section{Statistical analysis}

The antioxidant activity as FRAP (mg AAE /g DW) and total polyphenol content as TPC (mg GAE /g DW) values were shown as means \pm standard deviations. Datas were analyzed by the IBM SPSS Statistics 23, using one-way ANOVA to compare the FRAP and TPC values of each cultivar, where the significance level was set at $\mathrm{p}<0.05$. Homogeneity of variances was checked by Levene's test.

\section{Results}

\section{Effect of genotype}

\section{Dörgicse}

According to our study in Dörgicse, significant differences were observed among all the Lavandula cultivars investigated concerning values of FRAP $(\mathrm{p}<0.0001)$ and TPC $(\mathrm{p}<0.0001)$ (Table 2). Among L. angustifolia varieties ('Hidcote' and 'Munstead') significant differences were found regarding values of FRAP $(\mathrm{p}<0.005)$ and TPC $(\mathrm{p}<0.002) . \quad$ L. $\times$ intermedia cultivars ('Grosso' and 'Grappenhall') also differed significantly at FRAP $(\mathrm{p}<0.0001)$ and TPC $(\mathrm{p}<0.002)$ values. The lowest FRAP content was possessed by 'Munstead' (104.9 mg AAE/g DW), while the highest value was represented by 'Grosso' (179.6 mg AAE/g DW) (Figure 1). That tendency was observed at TPC values either: lowest value was detected at by
'Munstead' (113.3 mg GAE/g DW), and the highest value at 'Grosso' (152.4 mg GAE/g DW). In this respect, correlation was found between antioxidant activity and total polyphenol content values of the cultivars.

\section{Szomód}

In Szomód FRAP and TPC values of all the cultivars involved differed significantly $(\mathrm{p}<0.0001)$ (Table 2.). However, FRAP values did not changed considerably neither between $L$. angustifolia varieties ('Hidcote' and 'Munstead') ( $\mathrm{p}<0.151)$, nor between $L$. × intermedia cultivars ('Grosso' and 'Grappenhall') $(\mathrm{p}<0.251)$ did not differed significantly. Besides, significant differences were observed concerning TPC values of 'Hidcote' and 'Munstead' $(\mathrm{p}<0.026)$ and in the case of 'Grosso' and 'Grappenhall' ( $\mathrm{p}<0.046)$ (Table 2).

It was also found that the antioxidant capacity $(116.8 \mathrm{mg}$ AAE/g DW) as well as TPC (93.4 mg GAE/g DW) values were the lowest at 'Munstead' among all the cultivars investigated (Figure 2). However, the highest values of FRAP (150.3 mg AAE/g DW) and TPC (140.8 mg GAE/g DW) were detected at 'Grappenhall' (Figure 2).

\section{Effect of growing areas}

Regarding antioxidant capacity (FRAP), the effect of growing area was significant only at 'Grosso' $(p<0.0001)$. However, in the case of total polyphenol content (TPC) values, significant differences were found at all the investigated varieties (Table 3). The total polyphenol content values at Lavandula cultivars were higher in Dörgicse than in Szomód, except for 'Grappenhall' (Figure 4). According to soil analyses, higher amounts of $\mathrm{CaCO}_{3}$ and macronutrients (NPK) were measured in Szomód, while the soil of Dörgicse was richer in meso- and microelements (Table 1/b). The differences in precipitation prior to harvest between the growing areas was also considerable $(38.3 \mathrm{~mm})$ (Table 1/c). These ecological features might have effect on the polyphenol biosynthesis of Lavandula varieties involved.

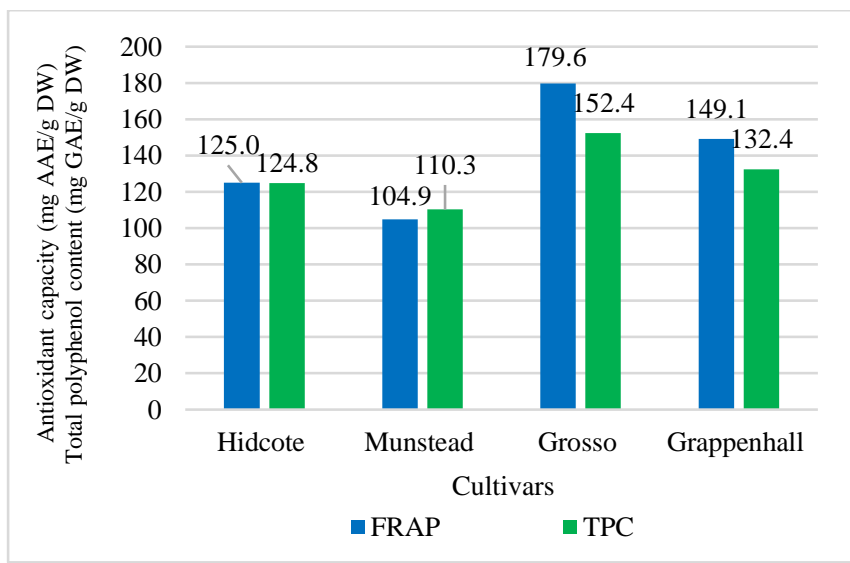

Figure 1. Antioxidant capacity (FRAP: mg AAE/g DW) and total polyphenol content (TPC: mg GAE/g DW) values of L. angustifolia and L. $\times$ intermedia cultivars in Dörgicse (2017). 


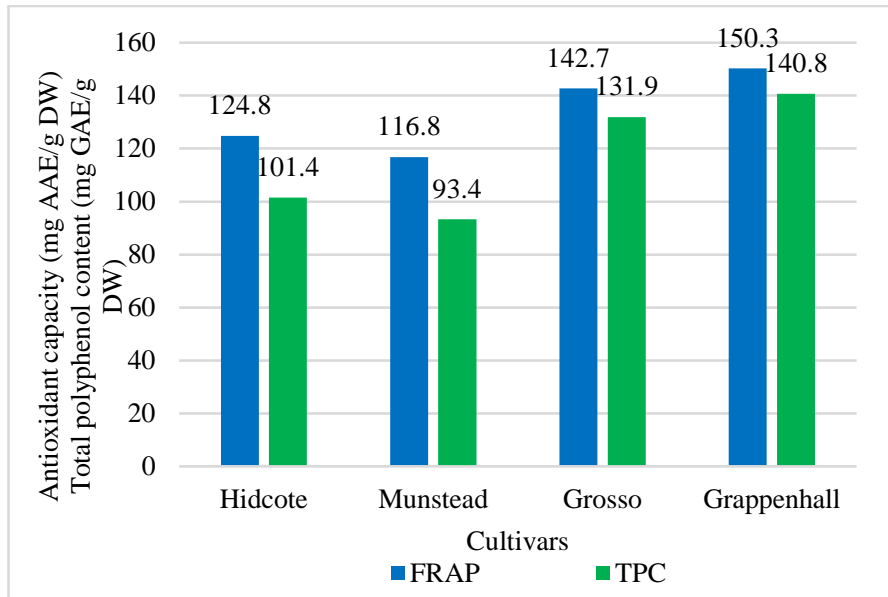

Figure 2. Antioxidant capacity (FRAP: mg AAE/g DW) and total polyphenol content (TPC: $\mathrm{mg} \mathrm{GAE} / \mathrm{g} \mathrm{DW}$ ) values of $L$. angustifolia and $L . \times$ intermedia cultivars in Szomód (2017).

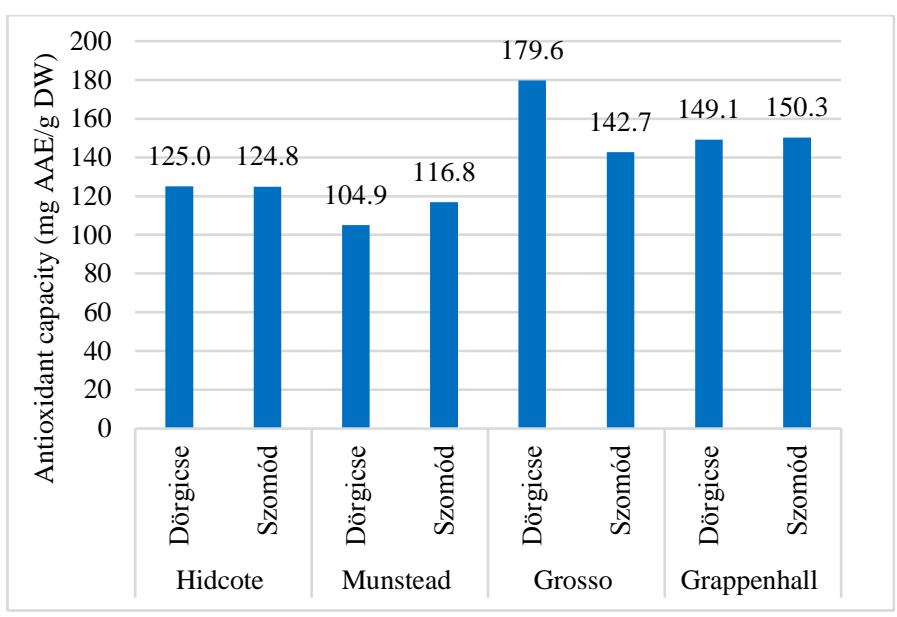

Figure 3. Antioxidant capacity (FRAP: $\mathrm{mg}$ AAE/g DW) of L. angustifolia and L. $\times$ intermedia cultivars in Dörgicse and Szomód (2017).

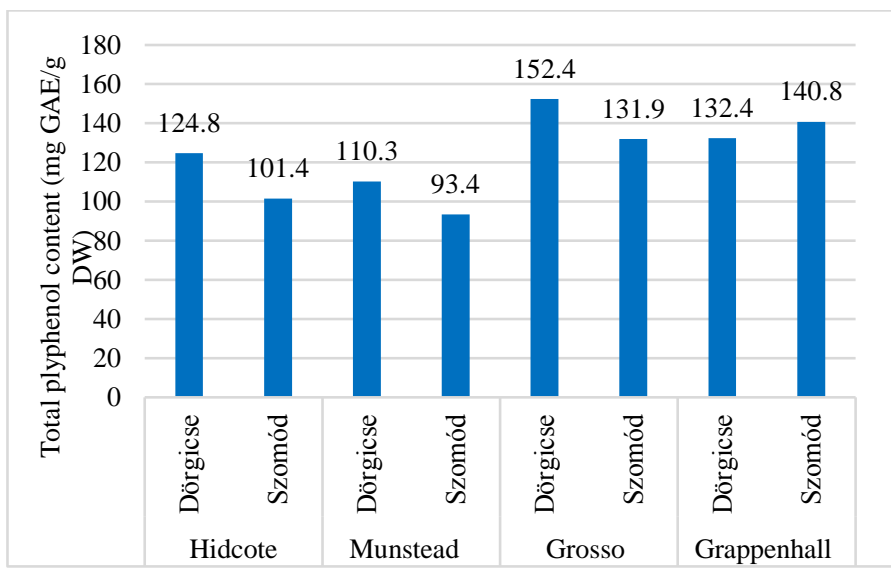

Figure 4. Total polyphenol content (TPC: $\mathrm{mg} \mathrm{GAE} / \mathrm{g} \mathrm{DW})$ of L. angustifolia and L. $\times$ intermedia cultivars in Dörgicse and Szomód (2017).

\section{Discussion}

According to our results, it can be concluded that statistically proven differences were found concerning antioxidant capacity values (FRAP), influenced by the genotype of Lavandula cultivars, regardless of the growing areas. Besides, it was observed, that the variability of antioxidant capacity values was higher in Dörgicse than in Szomód. Moreover, only FRAP values of 'Grosso' were significantly affected by the growing area
( $p<0.0001)$ (Table 3). On the contrary, total polyphenol content values of lavender samples differed significantly not only by the genotype (Table 2) but also by the growing area (Table 3). Therefore, it was important to summarize the main characteristics of the cultivars, as a conclusion of this study.

Table 3. Evaluation of the effect of growing area on the antioxidant capacity (FRAP) and total polyphenol content (TPC) of cultivars involved.

\begin{tabular}{|c|c|c|c|}
\hline \multirow{2}{*}{ Species } & \multirow{2}{*}{ Cultivars } & \multicolumn{2}{|c|}{ Effect of growing area } \\
\cline { 3 - 4 } & & FRAP & TPC \\
\hline \multirow{2}{*}{ L. angustifolia } & 'Hidcote' & $\mathrm{p}<0.6280$ & $\mathrm{p}<0.0001^{* *}$ \\
\cline { 2 - 4 } & 'Munstead' & $\mathrm{p}<0.0620$ & $\mathrm{p}<0.0001^{* *}$ \\
\hline \multirow{2}{*}{ L. x intermedia } & 'Grosso' & $\mathrm{p}<0.0001^{* *}$ & $\mathrm{p}<0.0020^{* *}$ \\
\cline { 2 - 4 } & 'Grappenhall' & $\mathrm{p}<0.8000$ & $\mathrm{p}<0.0010^{* *}$ \\
\hline
\end{tabular}

Legends: *: significant difference at $\mathrm{p}<0.05$; **: significant difference at $\mathrm{p}<0.01$

Table 4. Correlation between the antioxidant capacity (FRAP) and total polyphenol content (TPC) values of cultivars involved in different growing areas.

\begin{tabular}{|c|c|c|c|}
\hline \multirow{2}{*}{ Species } & \multirow{2}{*}{ Cultivars } & \multicolumn{2}{|c|}{ Growing area } \\
\cline { 3 - 4 } & & Dörgicse & Szomód \\
\hline \multirow{2}{*}{ L. angustifolia } & 'Hidcote' & $\mathrm{p}<0.9700$ & $\mathrm{p}<0.0001^{* *}$ \\
\cline { 2 - 4 } & 'Munstead' & $\mathrm{p}<0.2090$ & $\mathrm{p}<0.0001^{* *}$ \\
\hline \multirow{2}{*}{ L. x intermedia } & 'Grosso' & $\mathrm{p}<0.0001^{* *}$ & $\mathrm{p}<0.1110$ \\
\cline { 2 - 4 } & 'Grappenhall' & $\mathrm{p}<0.0001^{* *}$ & $\mathrm{p}<0.0320^{*}$ \\
\hline
\end{tabular}

Legends: *: significant difference at $\mathrm{p}<0.05 ; * *$ : significant difference at $\mathrm{p}<0.01$

\section{'Hidcote'}

Among L. angustifolia cultivars, 'Hidcote' possessed the highest values of antioxidant activity (125.0 mg AAE/g DW) and total polyphenol content (124.8 $\mathrm{mg}$ GAE/g DW) in both growing areas (Figure 3-4). The values of FRAP and TPC in Dörgicse were almost the same (125.0 mg AAE/g DW and 124.8 $\mathrm{mg} \mathrm{GAE} / \mathrm{g} \mathrm{DW})(\mathrm{p}<0.970)$, however, in Szomód larger variability could be observed in these values $(\mathrm{p}<0.0001)($ Table 4), which could be due to the lower TPC values (Figure 2).

\section{'Munstead'}

This variety represented the lowest values of antioxidant activity (104.6 mg AAE/g DW) and total polyphenol content (93.4 mg GAE/g DW) in both growing areas (Figure 3-4). Values of FRAP and TPC in Dörgicse did not differed significantly $(p<0.209)$, however, as in the case of 'Hidcote', in Szomód these values showed significant differences $(\mathrm{p}<0.0001)$ (Table 4).

\section{'Grosso'}

The FRAP and TPC values were the highest at this variety among the cultivars involved (FRAP: $179.6 \mathrm{mg}$ AAE/g DW; TPC: 152.4 mg GAE/g DW, both in Dörgicse). At 'Grosso', antioxidant capacity and total polyphenol content values were significantly influenced by the effect of growing area (FRAP: $p<0.0001$, and TPC: $\mathrm{p}<0.002)$ (Table 3). According to statistical analyses between FRAP and TPC values of 'Grosso' significant differences were observed in Dörgicse $(p<0.0001)$, while these values did not differed significantly in Szomód $(\mathrm{p}<0.111)$ (Table 4).

\section{'Grappenhall'}

In Szomód this variety represented the highest values of FRAP and TPC among Lavandula varieties, respectively (FRAP: $150.3 \mathrm{mg}$ AAE/g DW, and TPC: $140.8 \mathrm{mg} \mathrm{GAE} / \mathrm{g} \mathrm{DW})$ (Figure 2). According to statistical analyses between FRAP and TPC values of 'Grappenhall' in Dörgicse significant differences were observed $(\mathrm{p}<0.0001)$, moreover these values also differed significantly in Szomód $(\mathrm{p}<0.032)$ (Table 4). 
Evaluating the investigated cultivars, we concluded, that the two L. × intermedia cultivars, 'Grosso' and 'Grappenhall' may be candidates for Hungarian growers in order to contribute higher antioxidant capacity values of the products created. Antioxidant activity values of 'Grosso' were more variable by the growing areas, besides in this respect 'Grappenhall' was a more stable cultivar.

According to our knowledge, Lavandula species prefers dry and calcareous soil (Bernáth et al., 2013). In the soil of Dörgicse less $\mathrm{CaCO}_{3}$ values $(\mathrm{m} / \mathrm{m} \%)$ and higher microelement amounts were detected, which also could induce accelerated secondary metabolite production (polyphenols). This might be an explanation to the high FRAP and TPC values of 'Grosso' and higher TPC values of the other Lavandula cultivars from Dörgicse. However, our findings do not correspond to those reported by previous authors (Trócsányi et al., 2015; NémethZámbori et al., 2016; Radácsi et al., 2016) concerning drought stress reactions of other xerofil species, such as Thymus vulgaris. According to their results, it was concluded that more polyphenols, such as rosmarinic acid were detected in thyme and lemon balm plants as a consequence of water deficiency, while in our experiment this phenomenon was not observed in the growth year of 2017. Lavandula cultivars, especially 'Grosso', showed higher total polyphenol content values in the growing area of Dörgicse, where more precipitation was detected. However, further investigations are needed to confirm our findings concerning factors influencing polyphenol production of Lavandula cultivars among different growing conditions, completed by HPLC analysis of phenolic compounds.

\section{Acknowledgements}

This work had been supported by the Ministry for Innovation and Technology within the framework of the Higher Education Institutional Excellence Program (NKFIH-1159-6/2019) in the scope of plant breeding and plant protection research of SZIU". Besides, the authors are very thankful to Ildikó Demján, (Levendula Major Kft., Dörgicse, Hungary) and to József Tóth (Szomódi Levendulás, Szomód, Hungary), to gave us the opportunity to visit the lavender fields and to provide plant materials to the experiments.

\section{References}

Andrys, D., Kulpa, D., Grzeszczuk, M., Bihun, M., Dobrowolska, A. (2017): Antioxidant and antimicrobial activities of Lavandula angustifolia Mill. field-grown and propagated in vitro. Folia Hort. 159-178. doi: 10.1515/fhort-2017-0016

Benzie, I. F. F., Strain, J. J. (1996): The Ferric Reducing Ability of Plasma (FRAP) as a Measure of "Antioxidant Power": The FRAP Assay, Analytical Biochemisrty. 239: 70-76

Bernáth, J. (2013): Vadon termő és termesztett gyógynövények, Mezőgazda kiadó, Budapest, ISBN 978-963286-674-1, 320-324

Blažeković, B., Vladimir-Knežević, S., Brantner A., Štefan, B. M. (2010): Evaluation of Antioxidant Potential of Lavandula $\times$ intermedia Emeric ex Loisel. 'Budrovka': A Comparative Study with L. angustifolia Mill. Molecules. 15: 5971-5987. doi:10.3390/molecules15095971

Ceylan, Y., Ustab, K., Ustab, A., Maltasc, E., Yildiz, S. (2015): Evaluation of Antioxidant Activity, Phytochemicals and ESR Analysis of Lavandula Stoechas. Acta Phys Pol A. (128)2-B. doi: 10.12693/APhysPolA.128.B-483

Darbre, P. D., Aljarrah, A., Miller, W. R., Coldham, N. G., Sauer, M. J., Pope, M. G. (2004): Concentrations of parabens in human breast tumours. J. Appl. Toxicol. 24: 5-13. doi: 10.1002/jat.958

Duda, S. C., Marghitas L. A., Dezmireana, D., Duda M., Margaoan, R., Bobis O. (2015): Changes in major bioactive compounds with antioxidant activity of Agastache foeniculum, Lavandula angustifolia, Melissa officinalis and Nepeta cataria: Effect of harvest time and plant species. Ind. Crops and Prod. 77: 499-507. https://doi.org/10.1016/j.indcrop.2015.09.045

Grant, W., Zerihun, D., Mark, R., Soheil, M. (2011): Biosynthesis and Therapeutic Properties of Lavandula Essential Oil Constituents. Planta Med. 77(1): 7-15. DOI: 10.1055/s0030-1250136

Lis-Balchin, M. (2002): Lavender, The genus Lavandula. Taylor and Francis. ISBN 0-415-28486-4. pp. 11-13. 86-90. 117-170. 206-214

Németh-Zámbori, É., Pluhár, Zs., Szabó, K., Malekzadeh, M., Radácsi, P., Inotai, K., Komáromi, B., SeidlerLozykowska, K. (2016): Effect of water supply on growth and polyphenols of lemon balm (Melissa Officinalis L.) and thyme (Thymus Vulgaris L.), Acta Biologica Hungarica 67(1):64-74. DOI: 10.1556/018.67.2016.1.5

Nurzyńska-Wierdak R., Zawiślak G. (2016): Chemical composition and antioxidant activity of lavender (Lavandula angustifolia Mill.) aboveground. Acta Sci. Pol. Hortorum Cultus, 15(5): 225-241. ISSN 1644-0692

Radácsi, P., Szabó, K., Szabó, D., Trócsányi, E., NémethZámbori, É. (2016): Effect of water deficit on yield and quality of lemon balm (Melissa officinalis L.), ZemdirbysteAgriculture, 103(4): 385-390. DOI 10.13080/z-a.2016.103.049

Sánchez-Vioque, R., Polissiou, M., Astraka, K., MozosPascual, M. de los, Tarantilis, P., Herraiz-Pẽnalver, D., Santana-Méridas, O. (2013): Polyphenol composition and antioxidant and metal chelating activities of the solid residues from the essential oil industry, Ind. Crops and Prod., 49: 150 159. DOI: 10.1016/j.indcrop.2013.04.053

Shafaghat, A., Salimi, F., Amani-Hooshyar, V. (2012): Phytochemical and antimicrobial activities of Lavandula officinalis leaves and steams against some pathogenic microorganisms. J. Med. Plants Res. 6: 455-460. DOI: 10.5897/JMPR11.1166

Singleton, V. L., Rossi, J. A. Jr. (1965): Colorunetry of total phenolics with phosphomolybdic-phosphotungstic acid reagents. Amer. J. Enol. Viticult. 16: 144-58

Torras-Claveria, L., Jauregui, O., Bastida, J., Codina, C., F. Viladomat, (2007): Antioxidant Activity and Phenolic Composition of Lavandin (Lavandula $x$ intermedia Emeric ex Loiseleur) Waste, J. Agric. Food Chem., 55: 8436-8443. DOI: 10.1021/jf070236n

Trócsányi, E., György, Zs., Inotai, K., Szabó, K., Pluhár, Zs., Radácsi, P., Malekzadeh, M., Németh-Zámboriné, É. (2015): Enhanced rosmarinic acid accumulation and rosmarinic acid synthase gene expression under drought stress in thyme (Thymus vulgaris), Planta Med., 81:246, DOI: 10.1055/s-0035-1565623

Zielinska, S., Matkowski, A. (2014): Phytochemistry and bioactivity of aromatic and medicinal plants from the genus Agastache (Lamiaceae). Phytochem. Rev. 13: 391-416 